\title{
Antibacterial Peptide BSN-37 Kills Extra- and Intra-Cellular Salmonella enterica Serovar Typhimurium by a Nonlytic Mode of Action
}

\author{
Lei Yang, Yawei Sun*, Yanzhao Xu, Bolin Hang, Lei Wang, Ke Zhen, Bing Hu, \\ Yanan Chen, Xiaojing Xia and Jianhe Hu* \\ College of Animal Science and Veterinary Medicine, Henan Institute of Science and Technology, Xinxiang, China
}

OPEN ACCESS

Edited by:

Jayachandran N. Kizhakkedathu, The University of British Columbia,

Canada

Reviewed by:

Praveen Rishi,

Panjab University, India Jie Zheng,

United States Food and Drug

Administration, United States

*Correspondence:

Yawei Sun

sunyawei1975@126.com Jianhe Hu

xxianhe@126.com

Specialty section:

This article was submitted to Antimicrobials, Resistance

and Chemotherapy,

a section of the journa

Frontiers in Microbiology

Received: 26 October 2019

Accepted: 24 January 2020

Published: 07 February 2020

Citation:

Yang $L$, Sun $Y, X U Y$, Hang $B$, Wang L, Zhen K, Hu B, Chen Y, Xia X and Hu J (2020) Antibacterial Peptide BSN-37 Kills Extra- and Intra-Cellular Salmonella enterica Serovar

Typhimurium by a Nonlytic Mode of Action. Front. Microbiol. 11:174. doi: 10.3389/fmicb.2020.00174
The increasing rates of resistance to traditional anti-Salmonella agents have made the treatment of invasive salmonellosis more problematic, which necessitates the search for new antimicrobial compounds. In this study, the action mode of BSN-37, a novel antibacterial peptide (AMP) from bovine spleen neutrophils, was investigated against Salmonella enterica serovar Typhimurium (S. Typhimurium). Minimum inhibitory concentrations (MICs) and time-kill kinetics of BSN-37 were determined. The cell membrane changes of S. Typhimurium CVCC541 (ST) treated with BSN-37 were investigated by testing the fluorescence intensity of membrane probes and the release of cytoplasmic $\beta$-galactosidase activity. Likewise, cell morphological and ultrastructural changes were also observed using scanning and transmission electron microscopes. Furthermore, the cytotoxicity of BSN-37 was detected by a CCK-8 kit and real-time cell assay. The proliferation inhibition of BSN-37 against intracellular S. Typhimurium was performed in Madin-Darby canine kidney (MDCK) cells. The results demonstrated that BSN-37 exhibited strong antibacterial activity against ST (MICs, $16.67 \mu \mathrm{g} / \mathrm{ml}$ ), which was not remarkably affected by the serum salts at a physiological concentration. However, the presence of $\mathrm{CaCl}_{2}$ led to an increase in MIC of BSN-37 by about 4-fold compared to that of ST. BSN-37 at the concentration of $100 \mu \mathrm{g} / \mathrm{ml}$ could completely kill ST after co-incubation for 6 h. Likewise, BSN-37 at different concentrations (50, 100, and $200 \mu \mathrm{g} / \mathrm{ml}$ ) could increase the outer membrane permeability of ST but not impair its inner membrane integrity. Moreover, no broken and ruptured cells were found in the figures of scanning and transmission electron microscopes. These results demonstrate that BSN-37 exerts its antibacterial activity against $S$. Typhimurium by a non-lytic mode of action. Importantly, BSN-37 had no toxicity to the tested eukaryotic cells, even at a concentration of $800 \mu \mathrm{g} / \mathrm{ml}$. BSN-37 could significantly inhibit the proliferation of intracellular $S$. Typhimurium.

Keywords: antibacterial peptide BSN-37, Salmonella enterica serovar Typhimurium, antibacterial activity, action mode, eukaryotic cells, cytotoxicity 


\section{INTRODUCTION}

Salmonella enterica serovar Typhimurium (S. Typhimurium) is an important etiological agent responsible for invasive salmonellosis, which can be treated with antibacterial agents. However, the appearance and spread of multidrug-resistant S. Typhimurium has created a clinical dilemma for the treatment of invasive salmonellosis (Crump et al., 2015; Balasubramanian et al., 2019). Therefore, searching for new antibacterial compounds to treat invasive salmonellosis has become inevitable and urgent. Antimicrobial peptides (AMPs) are plausible candidates for the design of new antibacterial agents.

Antimicrobial peptides in living organisms are important components of innate immunity to microbial infections (Spänig and Heider, 2019). More than 3,000 AMP sequences have been registered in the antibacterial peptide database ${ }^{1}$. Among them, cathelicidins are one of the best characterized AMP families. Each cathelicidin includes an N-terminal signal domain, a cathelin-like domain, and an antimicrobial C-terminal domain. To defend against microbial attack in vivo, C-terminal domains in the AMPs are released and become mature peptides that exhibit biological activities. The proline-rich peptides (PRPs) are important members of the cathelicidin family, which contain high numbers of proline and arginine in mature sequences. In recent years, the PRPs have been attracting the close attention of researchers due to its strong antibacterial activity against Gramnegative bacteria, remarkably low toxicity toward mammalian cells, and the lack of extensive membrane-damaging effects (Ramanathan et al., 2002; Mishra et al., 2018). Bac5 is the first member of the PRPs among the cathelicidins family which demonstrated effective antibacterial activity against Escherichia coli ATCC 25922, S. Typhimurium LT2, S. Typhimurium ATCC14028, and Klebsiella pneumoniae ATCC1388 (MICs, 12$25 \mu \mathrm{g} / \mathrm{ml}$ ). Moreover, Bac5 at the concentration of $50 \mu \mathrm{g} / \mathrm{ml}$ can completely kill S. Typhimurium ATCC14028 after co-incubation for 60 min (Gennaro et al., 1989). Active Bac5 is comprised of 42 amino acid residues with a repeated pattern of Arg-ProPro triplets. Since Bac5 lacks any cysteine residue, it cannot form a disulphide bridge and exists in a linear conformation (Price et al., 2019). Research has found that the presence of Arg residues at or near the N-terminus and a chain length exceeding 15 residues, are required for the truncated fragments to exhibit antibacterial activity to E. coli IFO 12743, Staphylococcus aureus IFO12732, and Bacillus subtilis IFO 3134. When the first four residues in the N-terminus of Bac5(1-23) were deleted, Bac5(4-23) lost antibacterial activity (Tokunaga et al., 2001). Bac5(1-25) and Bac5(1-31) entered E. coli BW25113 mainly through the inner membrane transport proteins, SbmA. In the cytoplasm, the two peptides prohibited the protein from synthesizing by directly binding to the peptide exit tunnel in the $70 \mathrm{~S}$ ribosomes. However, the inhibition ability of Bac5(125) and Bac5(1-31) seems to be species-specific due to the low affinity exhibited for Thermus thermophilus $70 \mathrm{~S}$ ribosomes (Mardirossian et al., 2018). Furthermore, Bac5(1-25) was the best truncated fragment according to a comprehensive evaluation

${ }^{1}$ http://aps.unmc.edu/AP/main.php of antibacterial activity, cytotoxicity, and inhibition efficacy of protein synthesis (Mardirossian et al., 2019).

The Bac5 pre-pro peptide is actively synthesized in immature myeloid cells and comprises a 29-amino acid signal peptide followed by a 101-amino acid pro-region. After removal of the signal peptide, ProBac5 is stored in large cytoplasmic granules of bovine neutrophils (Zanetti et al., 1990). When peripheral neutrophils are activated, ProBac5 is secreted and forms the active AMP after the digestion of elastase from the azurophils (Scocchl et al., 1992). At present, the large granules have only been reported in the neutrophils of cow, goat, sheep, and deer, in which the Bac5 orthologs (QaBac5 $\alpha$, ChBac5, and P9) were also found (Shamova et al., 1999; Treffers et al., 2005). In the chromosome of sheep, four genes encoding PRPs (QaBac5, QaBac6, QaBac7.5, and QaBac11) have been identified. A naturally active C-terminal fragment of QaBac7.5 [QaBac7.5 mini (32-60)] and different naturally active N-terminal fragments of QaBac11 were purified from ovine neutrophil extract. The researchers speculated that these truncated active PRPs fragments might come from the cleavage of parent PRPs digested by peptidases (Anderson and Yu, 2003). Additionally, ChBac7N $\alpha(1-21)$ and $\mathrm{ChBac} 7 \mathrm{~N} \beta(1-22)$, two highly active $\mathrm{N}$-terminal fragments of PRP ChBac7.5, were also isolated from goat neutrophils. It was assumed that the fragmentation of mature cathelicidin-related AMPs may play a key role in different types of defense responses (Shamova et al., 2016). Except for the naturally active fragments of Bac7.5, three variants of QaBac5 (QaBac5 $\alpha$, QaBac5 $\beta$, and QaBac5 $\gamma$ ) and an N-terminal variant of ChBac5 (ChBac3.4) were also isolated from sheep and goat, respectively, which showed antibacterial activity to the tested bacteria (Anderson and Yu, 2003; Shamova et al., 2009). However, no naturally active truncated fragment of Bac5 was reported until we found BSN-37, a truncated N-terminal fragment [Bac5(2-38)] of Bac5, from bovine spleen neutrophils in 2018 (Yang et al., 2018). Additionally, the action model of Bac5 and its truncated fragments against S. Typhimurium is not very clear.

Our previous experiments showed that BSN-37 exhibited good antibacterial activity to susceptible and multidrug-resistant S. Typhimurium and E. coli (MICs, 3.13-50 $\mu \mathrm{g} / \mathrm{ml}$ ). Moreover, BSN-37 at the concentration of $400 \mu \mathrm{g} / \mathrm{ml}$ exhibited low hemolytic rates $(\leq 1.34 \%)$ and had no toxicity to the tested eukaryotic cells. In this experiment, we further confirmed that BSN-37 killed S. Typhimurium by a non-lytic mode of action and could significantly inhibit the proliferation of intracellular $S$. Typhimurium.

\section{MATERIALS AND METHODS}

\section{Antimicrobial Peptides and Antibiotics}

Two peptides, BSN-37 (N-FRPPIRRPPIRPPFYPPFRPPIRPPIF PPIRPPFRPP-C) and pexiganan (N-KKLIKVFAKGFKKAKKLF KGIG-C), were prepared via solid-phase synthesis using 9fluorenylmethoxycarbonyl (F-moc) chemistry at GL Biochem Ltd., (Shanghai) and analyzed by HPLC and MALDI-TOF MS to confirm that the purity was $>95 \%$. Pexiganan is a synthetic 
analog of the peptide magainin II from the skin of the African clawed frog, Xenopus laevis, which exhibits a lytic mode of action against bacteria (Gottler and Ramamoorthy, 2009), and is used as a positive control in this study. Both peptides were dissolved in ultrapure water and used for the following experiments.

Amoxicillin and chloramphenicol were purchased from the National Institute for the Control of Pharmaceutical and Biological Products (Beijing, China).

\section{Bacterial Strains and Cells}

The strains of E. coli ATCC25922 and Staphylococcus aureus ATCC25923 were purchased from the American Type Culture Collection (ATCC, Manassas, VA, United States). The strain of $S$. Typhimurium CVCC541 was purchased from the China Institute of Veterinary Drug Control (CVCC, Beijing, China) and designated ST in this article. The strains of S. Typhimurium CMCC50097 and Staphylococcus albus CMCC261015 were purchased from the National Center for Medical Culture Collections (CMCC, Beijing, China). The strain of Salmonella pullorum BNCC124693 was purchased from the BeNa Culture Collection (BNCC, Suzhou, China). A clinical isolate of $S$. Typhimurium SB217 from a diseased chicken was identified by the VITEK-32 system (bioMérieux) and PCR amplification sequencing.

Porcine small intestinal epithelial cells (IPEC-J2), Vero cells, and Madin-Darby canine kidney (MDCK) epithelial cells were purchased from the American Type Culture Collection (ATCC, Manassas, VA, United States).

\section{Antimicrobial Measurements and Salt Sensitivity Assay}

Minimum inhibitory concentrations (MICs) of BSN-37, pexiganan, amoxicillin, and chloramphenicol were determined using the two-fold broth microdilution method according to the CLSI guidance (Clinical and Laboratory Standards Institute [CLSI], 2017). MIC values of the tested antibacterial agents were determined on three independent occasions.

Next, the effect of different salts on the antibacterial activity of BSN-37 was tested as described by Maisetta et al. (2018). MICs of BSN-37 against E. coli ATCC25922 and ST were measured in the presence of physiological concentrations of salts $(150 \mathrm{mM} \mathrm{NaCl}$, $4.5 \mathrm{mM} \mathrm{KCl}, 6 \mu \mathrm{M} \mathrm{NH} \mathrm{N}_{4} \mathrm{Cl}, 1 \mathrm{mM} \mathrm{MgCl}_{2}, 2.5 \mathrm{mM} \mathrm{CaCl}_{2}$, and $\left.4 \mu \mathrm{M} \mathrm{FeCl}_{3}\right)$.

\section{Time-Kill Kinetics Curve}

Time-kill kinetics of BSN-37 against ST was determined according to the following method. A solution of equal parts ST at a concentration of $5 \times 10^{5} \mathrm{CFU} / \mathrm{ml}$ in fresh Mueller-Hinton (MH) broth and BSN-37 at different concentrations $(0,100,200$, and $400 \mu \mathrm{g} / \mathrm{ml})$ were prepared and grown at $37^{\circ} \mathrm{C}$ without shaking. Each sample $(100 \mu \mathrm{l})$ was withdrawn at $0,1,2,4,6,8$, and $24 \mathrm{~h}$ and serially diluted in Luria-Bertani (LB) broth by a 10-fold decrease. The diluted bacteria were plated onto LB agar plates and cultured at $37^{\circ} \mathrm{C}$ for $18 \mathrm{~h}$ for the colony-forming unit (CFU) counts.

\section{Outer Cell Membrane Permeability}

The fluorescence of N-phenyl-1-naphthylamine (NPN) is weak in an aqueous environment but strong in non-polar or hydrophobic environments. In normal bacteria NPN is excluded from the outer cell membrane and does not fluoresce. If the outer membrane of bacteria is damaged, NPN partitions into the interior of the outer cell membrane, and an increase in fluorescence can be observed. Therefore, the outer membrane permeability of BSN-37 and pexiganan against ST was evaluated using an NPN uptake assay (Helander and Mattila-Sandholm, 2000). An overnight culture of $50 \mu \mathrm{l}$ was added into $5 \mathrm{ml}$ fresh $\mathrm{LB}$ and grown at $37^{\circ} \mathrm{C}$ with shaking at $250 \mathrm{rpm}$ to an optical density (OD) at $600 \mathrm{~nm}$ of 0.4 to 0.6 . The strains were harvested by centrifugation at $5000 \times g$ for $6 \mathrm{~min}$ and then washed twice in $5 \mathrm{mM}$ HEPES buffer containing $5 \mathrm{mM}$ glucose (working solution, $\mathrm{pH}$ 7.4). The bacterial sediment was resuspended in the working solution at an $\mathrm{OD}_{600}=1$. Further, $100 \mu \mathrm{l}$ bacteria suspension, $50 \mu \mathrm{l}$ working solution containing $40 \mu \mathrm{M} \mathrm{NPN}$, and $50 \mu \mathrm{l}$ peptide at different concentrations were added to a sterile 96-well plate and mixed. Fluorescence was monitored immediately in a multifunctional microplate reader (Infinite ${ }^{\circledR} 2000$, TECAN) at an excitation wavelength of $350 \mathrm{~nm}$ and an emission wavelength of $420 \mathrm{~nm}$ for $1 \mathrm{~h}$ at $1 \mathrm{~min}$ intervals.

\section{Inner Membrane Integrity}

The fluorescent probe, 3,3'-dipropylthiadicarbocyanine iodide [DiS-C3-(5)], is concentrated in the cytoplasmic membrane under the influence of the internally negative membrane potential, leading to self-quenching of the fluorescence. If peptides form channels or otherwise disrupt the membrane, the membrane potential will be dissipated, and the DiS-C3-(5) will be released into the medium, causing the fluorescence to increase. Therefore, the inner membrane integrity of ST treated with BSN-37 and pexiganan was tested using DiS-C3-(5) as a probe (Sautrey et al., 2016). ST was grown to the mid-logarithmic phase $\left(\mathrm{OD}_{600}=0.5-0.6\right)$ in LB broth and harvested by centrifugation at $5000 \times g$ for $6 \mathrm{~min}$. The cells were washed twice in a working solution and then resuspended in the same solution at an $\mathrm{A}_{600}=0.05$. After that, DiS- $\mathrm{C}_{3}-(5)$ at the final concentration of $0.8 \mathrm{mM}$ was added into the suspension. At the $\mathrm{DiS}_{-} \mathrm{C}_{3}-(5)$ uptake maximum, $100 \mathrm{mM} \mathrm{KCl}$ was added to equilibrate the cytoplasmic and external $\mathrm{K}^{+}$concentration. After incubation in the dark for $1 \mathrm{~h}$ at room temperature, each $180 \mu \mathrm{l}$ cell suspension was transferred to the wells supplied with $20 \mu \mathrm{l}$ BSN-37 at different concentrations on a 96-well black polystyrene microtiter plate (Corning, NY, United States). Congruently, pexiganan at the final concentration of $100 \mu \mathrm{g} / \mathrm{ml}$ was used as a control. Fluorescence intensity was monitored in a multifunctional microplate reader (Infinite ${ }^{\circledR} 2000$, TECAN) at an excitation wavelength of $620 \mathrm{~nm}$ and an emission wavelength of $670 \mathrm{~nm}$ for $30 \mathrm{~min}$ at $1 \mathrm{~min}$ intervals. Each experiment was repeated three times.

\section{$\beta$-Galactosidase Assay}

To determine if BSN-37 disrupts the inner cell membrane, the release of cytoplasmic $\beta$-galactosidase activity was measured in ST containing a fusion plasmid pKP302mdtk:lacZ using 
onitrophenyl- $\beta$-D-galactopyranoside (ONPG, Sigma, Germany) as a substrate according to a previously described method (Paytubi et al., 2017). Due to the deficiency of gene encoding $\beta$-galactosidase in ST, a fusion plasmid pKP302mdtk:lac $Z$ was first constructed according to the method shown in Figure 1. The primer set used to amplify the promoter region of the multidrug efflux pump, MdtK, in ST was
KLAF $\quad 5^{\prime}$-CCGAATTCGGTGCGAAAG-3' and KLAR 5'TTGGATCCGCCAGCAGTAA-3' (restriction sites are underlined). The primer set used to identify the fusion plasmid was PKPF 5'-TGCTCCATAACATCAAA CATCG-3' and PKPR 5'-GCATAACCACCACGCTCATC-3', which was located on the two sides of the inserted fragment in pKP302. Finally, the fusion plasmid pKP302mdtk:lacZ was transformed

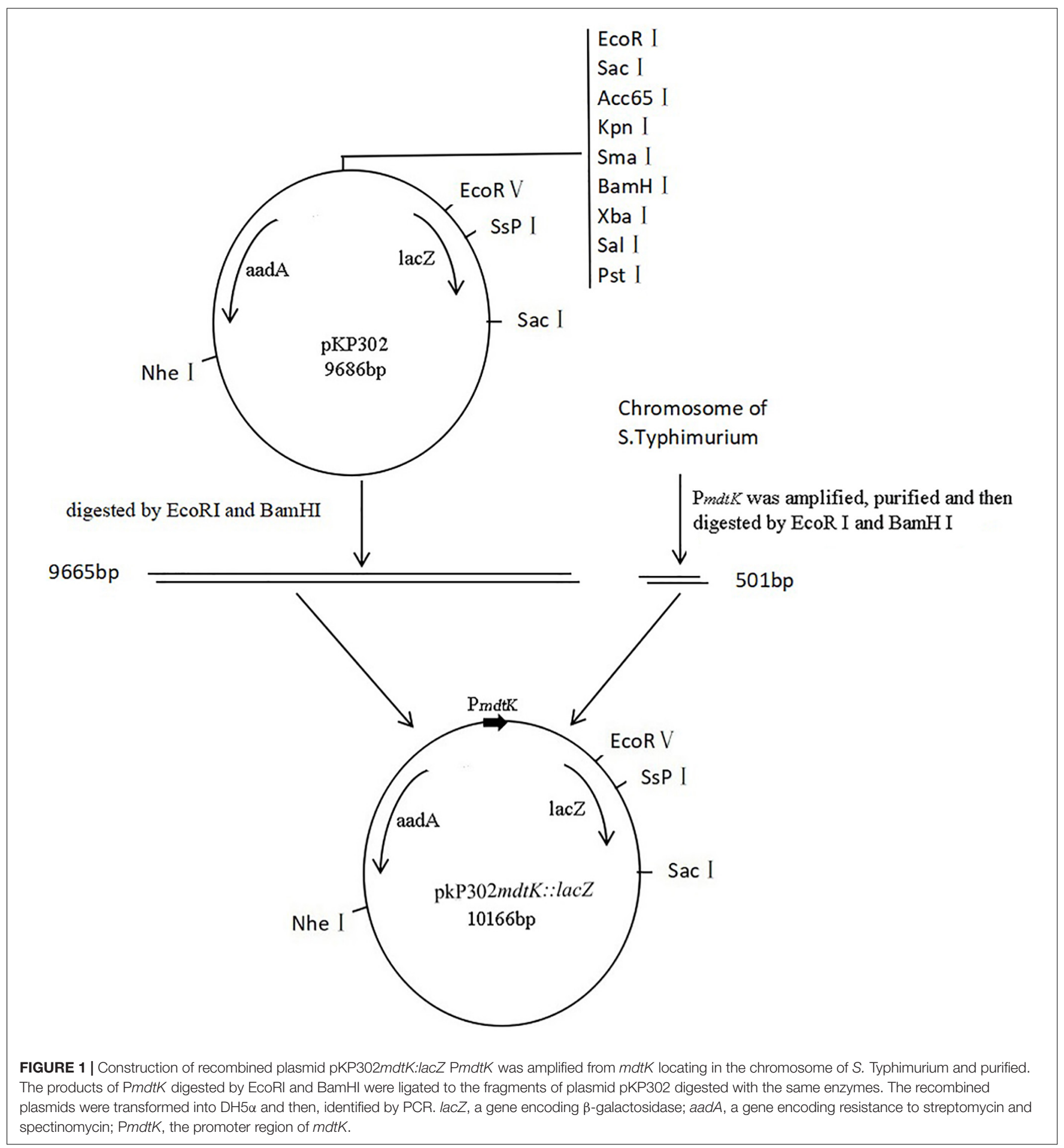


into ST by electroporation. Secondly, a $\beta$-galactosidase assay was performed. Briefly, overnight cultures of STpKP302 mdtk:lacZ were diluted (1:100) in LB medium containing $100 \mu \mathrm{g} / \mathrm{ml}$ spectinomycin and grown at $37^{\circ} \mathrm{C}$ with shaking at $250 \mathrm{rpm}$ to an $\mathrm{OD}_{600}=0.3-0.5$. The $\mathrm{OD}_{600}$ value was recorded. A culture of $200 \mu \mathrm{l}$ was pelleted and resuspended in $400 \mu \mathrm{l} \mathrm{Z}$-buffer $(0.06 \mathrm{M}$ $\mathrm{Na}_{2} \mathrm{HPO}_{4}, 0.04 \mathrm{M} \mathrm{NaH} \mathrm{PO}_{4}, 0.01 \mathrm{M} \mathrm{KCl}, 0.001 \mathrm{M} \mathrm{MgSO}_{4}$, and $0.05 \mathrm{M} \beta$-mercaptoethanol, $\mathrm{pH} 7.0$ ). After that, $20 \mu \mathrm{l}$ of chloroform and $10 \mu \mathrm{l}$ of SDS $0.1 \%(\mathrm{w} / \mathrm{v})$ were added, and the mixture was intensively vortexed for $15 \mathrm{~s}$. The sample was used as a positive control. Alternatively, each $200 \mu \mathrm{l}$ culture sediment was individually resuspended in $400 \mu \mathrm{l}$ PBS buffers $(10 \mathrm{mM})$ supplied with different concentrations of BSN-37 $(0,50,100$, and $200 \mu \mathrm{g} / \mathrm{ml}$ ). All samples were incubated at $30^{\circ} \mathrm{C}$ for $1,2,4$, or $6 \mathrm{~h}$. At each incubation ends, the reaction was initiated by the addition of $80 \mu \mathrm{l} \mathrm{ONPG}(4 \mathrm{mg} / \mathrm{ml})$. Once the reaction began to turn yellow, it was quenched by the addition of $200 \mu \mathrm{l}$ sodium carbonate $(1 \mathrm{M})$. After $5 \mathrm{~min}, \mathrm{OD}_{420} \mathrm{~nm}$ and $\mathrm{OD}_{550} \mathrm{~nm}$ of the reaction mixtures were determined, and $\beta$-galactosidase activity (Miller Units) was calculated using the following formula: Miller Units $=1000 \times\left(\mathrm{OD}_{420}-1.75 \times \mathrm{OD}_{550}\right) /$ [volume $(\mathrm{ml}) \times$ time $\left.(\mathrm{min}) \times \mathrm{OD}_{600}\right]$. Enzymatic determinations were performed in duplicates of at least three independent experiments.

\section{Scanning Electron Microscopy}

To reduce the effect of the centrifugation on the morphology of the bacteria, an improved SEM operation procedure was followed as described below. Sterile slides were placed into 24 -well plates with $1 \mathrm{ml} \mathrm{MH}$ broth in each well. An overnight culture of $10 \mu \mathrm{l}$ ST was added into each well and cultured at $37^{\circ} \mathrm{C}$ for $4 \mathrm{~h}$. After incubation, the culture medium was replaced by $1 \mathrm{ml}$ BSN-37 at different concentrations $(50,100$, and $200 \mu \mathrm{g} / \mathrm{ml})$ and reacted for $1 \mathrm{~h}$. Alternatively, the slide treated with $50 \mu \mathrm{g} / \mathrm{ml}$ pexiganan and $10 \mathrm{mM}$ PBS buffer was used as a positive and negative control, respectively. After the slides in the wells were gently washed twice with warm PBS buffer, $400 \mu \mathrm{l}$ glutaraldehyde $(2.5 \%$, v/v) was added into each well to fix bacteria at $4^{\circ} \mathrm{C}$ overnight. The fixed bacteria were dehydrated for $15 \mathrm{~min}$ in a series of graded ethanol solutions $(30,50,70,80,90$, and $100 \%)$. The samples were transferred to a mixture $(1: 1)$ of ethanol and tertiary butanol for $15 \mathrm{~min}$ and then to pure tertiary butanol for $20 \mathrm{~min}$. After lyophilization and gold coating, the morphology of the bacteria was observed by SEM under a Quanta 200 FEG scanning electron microscope (FEI, Ltd.).

\section{Transmission Electron Microscope}

Transmission Electron Microscope imaging was performed as described previously (Shao et al., 2018). The working concentration of BSN-37 and pexiganan with cell suspensions was 200 and $50 \mu \mathrm{g} / \mathrm{ml}$, respectively. Finally, the specimens were sectioned with an ultramicrotome, stained with uranyl acetate and lead citrate, and observed using a Hitachi HT-7770 TEM (Hitachi, Japan).

\section{CCK-8 Assay}

The toxicity of BSN-37 and pexiganan against IPEC-J2 cells was determined using a CCK-8 assay kit (CCK-8,
Dojindo, Kumamoto, Japan). IPEC-J2 cells were cultured in Advanced DMEM/F12 medium (Gibco, Thermo Fisher Scientific, United States) supplied with $0.2 \mathrm{mM}$ L-glutamine (Gibco, Thermo Fisher Scientific, United States) and 5\% fetal bovine serum (Gibco, Thermo Fisher Scientific, United States) at $37^{\circ} \mathrm{C}$ in an atmosphere containing $5 \%$ carbon dioxide with a relative humidity of $86 \%$. Cells at approximately $2 \times 10^{5}$ cells $/ \mathrm{ml}$ were seeded into 96-well culture plates (100 $\mu \mathrm{l} /$ well). Peptides $(100 \mu \mathrm{l})$ at different concentrations $(50,100,200$, and $400 \mu \mathrm{g} / \mathrm{ml})$ were added into the wells. The wells containing cells without peptides served as controls. After incubating the plates for $24 \mathrm{~h}$, $10 \mu \mathrm{l} \mathrm{CCK}-8$ solution was added, the incubation continued for $2 \mathrm{~h}$ at $37^{\circ} \mathrm{C}$, and the absorbance at $450 \mathrm{~nm}$ was read with the aid of a multifunctional microplate reader (Infinite ${ }^{\circledR} 2000$, TECAN). The viability of the control cells was assumed to be $100 \%$. The viability of cells exposed to peptides was expressed as percentages of the control. This assay was performed in triplicate.

\section{Real-Time Cell Assay}

The xCELLigence system (ACEA Biosciences; San Diego, CA, United States) was used to detect IPEC-J2 cells and Vero cells proliferation according to a previously described method (Pauly et al., 2012). Cells seeded at 7500 cells/well and 10000 cells/well in 16-well E-plates were cultured to $\sim 60 \%$ confluency based on cell index (CI) values. Various concentrations of BSN-37 (50, 100, 200,400 , and $800 \mu \mathrm{g} / \mathrm{ml}$ ) were added to the treated cells and were incubated for $40 \mathrm{~h}$. Congruently, the pexiganan at a concentration of $100 \mu \mathrm{g} / \mathrm{ml}$ and the cells without AMP were used as a positive and negative control, respectively. The CI was automatically determined every $15 \mathrm{~min}$ by the xCELLigence system (ACEA Biosciences; San Diego, CA, United States). In the assay process, each sample $(100 \mu \mathrm{l})$ from the BSN-37(100 $\mu \mathrm{g} / \mathrm{ml})$-treated group and the positive control was withdrawn at random four times sites and used for the CFU counts. The cells' survival rates were decided and analyzed.

\section{In vitro Proliferation Inhibition of Intracellular Salmonella Assay}

To investigate the effect of BSN-37 on the proliferation of intracellular bacteria, a gentamicin protection assay was performed as previously described (Gerlach et al., 2008). In this experiment, ST and SB217 were used as invasive strains. MDCK cells $\left(1 \times 10^{5}\right.$ cells/well $)$ were plated on 24 -well plates for $24 \mathrm{~h}$. Cells were infected by ST or SB217 at a multiplicity of infection (MOI) of $10 \sim 100: 1$ to host cells. Cells were incubated with bacteria for $1 \mathrm{~h}$ at $37^{\circ} \mathrm{C}$, followed by $2 \mathrm{~h}$ of incubation in media containing $100 \mu \mathrm{g} / \mathrm{ml}$ gentamicin at $37^{\circ} \mathrm{C}$ to kill extracellular bacteria. The infected cells were divided into three groups. The first group was washed twice with warm PBS buffer and then lysed by adding $200 \mu \mathrm{l}$ of $1 \%$ Triton-100 for $10 \mathrm{~min}$. The lysate was used for the CFU counts. Invasion ability of the tested strains is expressed as a percentage of initial bacterial inoculum. The second and third groups were treated with 0 and $400 \mu \mathrm{g} / \mathrm{ml}$ of $\mathrm{BSN}-37$, respectively, in the presence of $10 \mu \mathrm{g} / \mathrm{ml}$ gentamicin for $14 \mathrm{~h}$ at $37^{\circ} \mathrm{C}$. After that, each group was also treated using the same method to that in the first group. Fold intracellular 
replication was calculated by dividing the intracellular bacterial load at $16 \mathrm{~h}$ by the intracellular bacterial load at $2 \mathrm{~h}$. Each experiment was performed three times.

\section{Statistical Analysis}

Statistical analyses were performed using GraphPad Prism 6.0 (GraphPad Software). Two-way ANOVA or unpaired Student's $t$-test were utilized where appropriate. The threshold of statistical significance was set at ${ }^{*} P<0.05,{ }^{* *} P<0.01$, ${ }^{* * *} P<0.001$, and $*_{* * *} P<0.0001$. Exact $P$-values are indicated in the figure legends, when applicable.

\section{RESULTS}

\section{Antibacterial Activity of BSN-37 and Serum Salts Effect}

The MICs of amoxicillin, chloramphenicol, BSN-37, and pexiganan against four typical Gram-negative and two Grampositive bacteria are shown in Table 1. BSN-37 showed antibacterial activity to the tested strains (MICs $\leq 50 \mu \mathrm{g} / \mathrm{ml}$ ) except for S. aureus ATCC25923. Among them, BSN-37 exhibited strong inhibitory action against $S$. Typhimurium. The MICs of BSN-37 against ST and S. Typhimurium CMCC50097 are 16.67 and $8.33 \mu \mathrm{g} / \mathrm{ml}$, respectively.

In general, the serum salts probably affected the antibacterial activity of AMPs in vivo. The MICs of BSN-37 against ST and E. coli ATCC25922 in the presence and absence of different serum salts at physiological concentrations are shown in Table 2. The MICs of BSN-37 against ST did not exhibit significant changes $(<1.5$-fold increase $)$ in the presence of the tested salts, except that $\mathrm{CaCl}_{2}$ led to MICs increase of about 4 -fold. In contrast, the antibacterial activity of BSN-37 shows strong inhibition against E. coli ATCC25922 with $\mathrm{NaCl}, \mathrm{MgCl}_{2}$, or $\mathrm{CaCl}_{2}$, which decreased its activity at least 6 -fold. The remaining salts, $\mathrm{KCl}, \mathrm{NH}_{4} \mathrm{Cl}$, and $\mathrm{FeCl}_{3}$, did not significantly affect the antibacterial activity of BSN-37 against E. coli ATCC25922.

\section{Bactericidal Kinetics of BSN-37}

BSN-37 exhibited strong bacteriostatic action against $S$. Typhimurium; therefore, the bactericidal kinetics of BSN-37 against ST was further studied by determining the time-kill curve. As shown in Figure 2, BSN-37 at the concentration of 100
TABLE 2 | Minimum inhibitory concentrations of BSN-37 in the presence and absence of physiological concentrations of different serum salts.

\begin{tabular}{lcc}
\hline Culture medium & \multicolumn{2}{c}{ Strains (unit: $\mu \mathbf{g} / \mathbf{m l}$ ) } \\
\cline { 2 - 3 } & E. coli ATCC25922 & ST \\
\hline $\mathrm{MH}$ broth $+\mathrm{NaCl}(150 \mathrm{mM})$ & 200 & 20.83 \\
$\mathrm{MH}$ broth $+\mathrm{KCl}(4.5 \mathrm{mM})$ & 50 & 16.67 \\
$\mathrm{MH}$ broth $+\mathrm{NH}_{4} \mathrm{Cl}(6 \mu \mathrm{M})$ & 50 & 16.67 \\
$\mathrm{MH}$ broth $+\mathrm{MgCl}_{2}(1 \mathrm{mM})$ & 200 & 25 \\
$\mathrm{MH}$ broth $+\mathrm{CaCl}_{2}(2.5 \mathrm{mM})$ & $>200$ & 66.67 \\
$\mathrm{MH}$ broth $+\mathrm{FeCl}_{3}(4 \mu \mathrm{M})$ & 50 & 12.5 \\
$\mathrm{MH}$ broth & 33.33 & 16.67
\end{tabular}

ST, S. enterica serovar Typhimurium CVCC541.

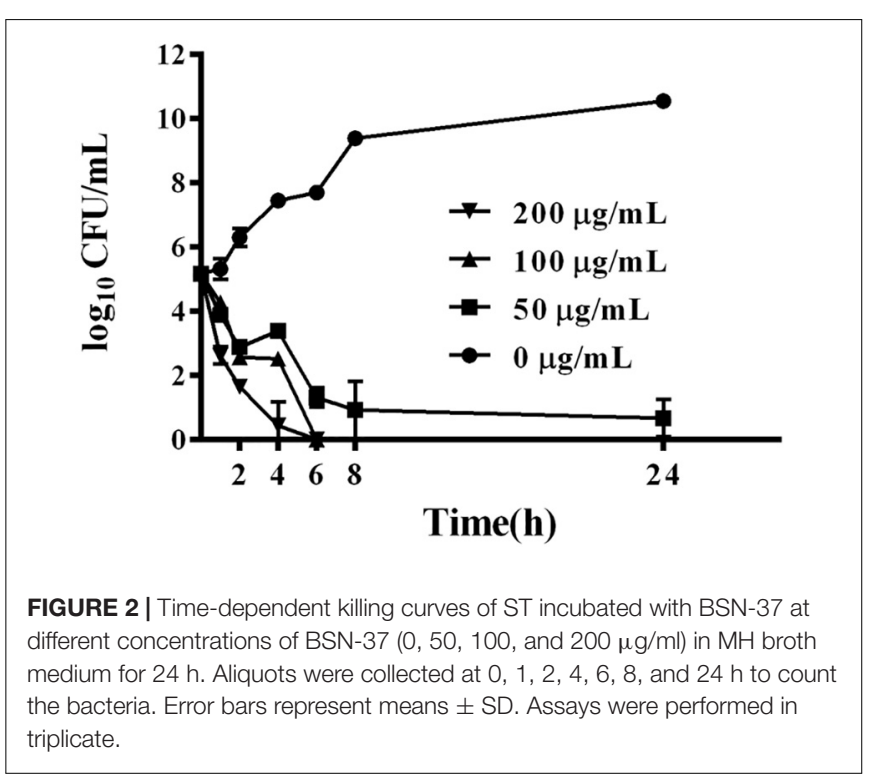

or $200 \mu \mathrm{g} / \mathrm{ml}$ completely killed the strain after co-incubation for $6 \mathrm{~h}$. However, BSN-37 at the concentration of $50 \mu \mathrm{g} / \mathrm{ml}$ did not completely kill the strain after co-incubation for $24 \mathrm{~h}$, although the concentration of the bacteria reduced from $1.45 \times 10^{5}$ to $8.43 \mathrm{CFU} / \mathrm{ml}$ in the first co-incubation for $8 \mathrm{~h}$. Likewise, BSN-37 exhibited concentration- dependent bactericidal action against $\mathrm{ST}$ in the co-incubation from $2 \mathrm{~h}$ to $6 \mathrm{~h}$.

TABLE 1 | Minimum inhibitory concentrations of the strains to antibiotics and antimicrobial peptides.

\begin{tabular}{|c|c|c|c|c|}
\hline Strains & \multicolumn{4}{|c|}{$\operatorname{MIC}(\mu \mathrm{g} / \mathrm{ml})$} \\
\hline E. coli ATCC25922 & 8 & 3.13 & 33.33 & 10.41 \\
\hline ST & 0.83 & 1.67 & 16.67 & 6.25 \\
\hline S. enterica serovar Typhimurium CMCC50097 & 2.67 & 2.67 & 8.33 & 6.25 \\
\hline S. pullorum BNCC124693 & 1.67 & 4 & 25 & 50 \\
\hline
\end{tabular}

AMO, amoxicillin; CHL, chloramphenicol; ST, S. enterica serovar Typhimurium CVCC541. 


\section{Effect of BSN-37 on the Cell Membrane of ST}

The interactions of BSN-37 and pexiganan with the outer membrane of ST were determined by testing the fluorescence of membrane probe NPN. As shown in Figure $\mathbf{3 A}$, the fluorescence units of the sample treated with $100 \mu \mathrm{g} / \mathrm{ml}$ pexiganan significantly increased in the first incubation for about 3 min to 13000 units. At the same time, the fluorescence units of the samples treated with BSN-37 at different concentrations also showed rapid increases in the first incubation for about 2 min. The max fluorescence unit is about 0.6 -fold of that produced by pexiganan. The rapid uptake of NPN demonstrates that BSN-37 and pexiganan can increase the outer membrane permeability of ST, and the efficiency of BSN-37 is weaker than that of pexiganan.

As shown in Figure 3B, pexiganan induced a large release of DiS-C $3-$ (5) (about 320AU) in the first incubation for about 2 min. However, BSN-37 at different concentrations only induced a little release of $\mathrm{DiS}_{-} \mathrm{C}_{3-}$ (5) (about $50 \mathrm{AU}$ ) during a similar incubation time, and the release is concentration-independent, which suggests that BSN-37 has little effect on the inner membrane integrity of ST.

When STpKP302mdtk:lacZ was treated with a permeabilization mixture containing Z-buffer, chloroform, and sodium dodecyl sulfate at different times, the $\beta$-galactosidase was immediately released (shown in Figure 3C, positive control). However, when STpKP302mdtk:lacZ was treated by BSN-37 at different concentrations and times, the $\beta$-galactosidase activities in the culture mediums did not exhibit a significant difference compared to that in the negative control (PBS buffer), which demonstrates that BSN-37 does impair the inner membrane integrity of ST.

\section{SEM and TEM}

To observe the effect of BSN-37 on the morphological and ultrastructural changes of ST, SEM, and TEM were used. As shown in Figure 4, the morphology of ST treated with $50 \mu \mathrm{g} / \mathrm{ml} \mathrm{BSN-37}$ was similar to the smooth and regular surface of the control treated with $10 \mathrm{mM}$ PBS. When cells

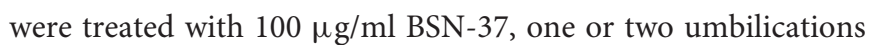
of the cell membrane in the middle of each bacterium were observed but no broken and ruptured cells were found. Even ST exposed to $200 \mu \mathrm{g} / \mathrm{ml}$ BSN-37 remained unlysed and showed obvious shrinkage in size regardless of the umbilications of the cell membrane. In contrast, atrophy, corrugation and poreforming were observed on the surface of the cell membrane of ST treated with $50 \mu \mathrm{g} / \mathrm{ml}$ pexiganan. Simultaneously, some intracellular materials leaked from the cell membrane, which formed aggregations and adhesions. Conversely, the TEM figures showed no significant change in morphology and cytoplasm structure of ST treated with $200 \mu \mathrm{g} / \mathrm{ml} \mathrm{BSN-37}$ when compared to that of the negative control (shown in Figure 5). However, morphological changes, substantial plasmolysis, the release of intracellular materials, and bacterial ghosts existed after ST was treated with $50 \mu \mathrm{g} / \mathrm{ml}$ pexiganan. In conclusion, these results concur with the changes of the cell membrane,
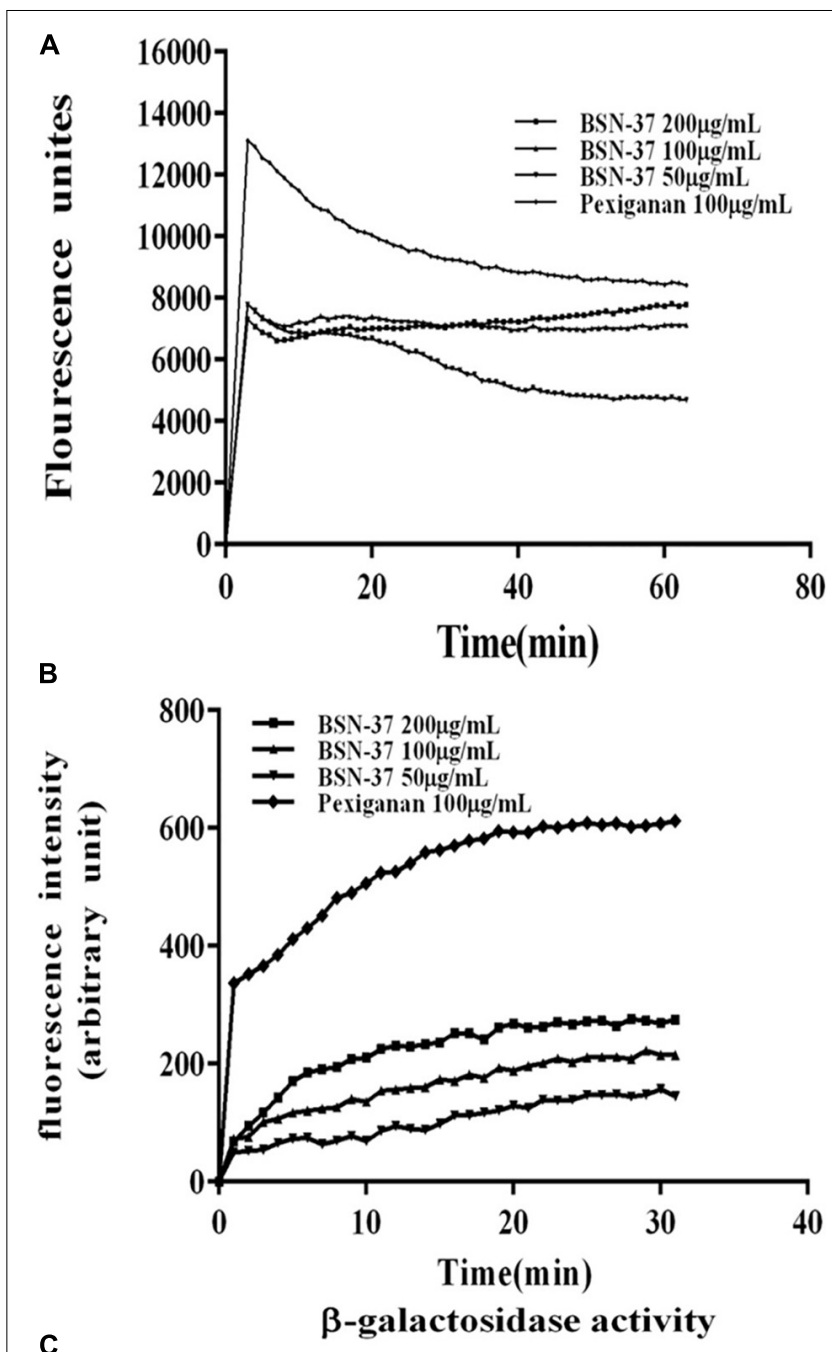

C

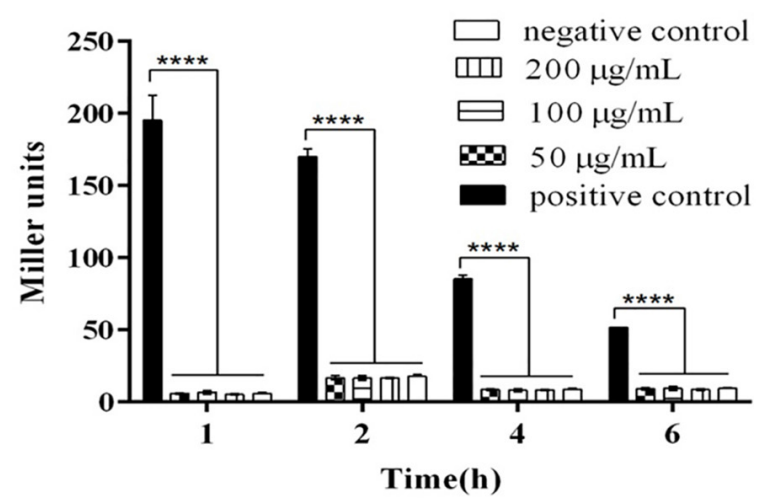

FIGURE 3 | The effect of BSN-37 at different concentrations (50, 100, and $200 \mu \mathrm{g} / \mathrm{ml}$ ) and pexiganan at the concentration of $100 \mu \mathrm{g} / \mathrm{ml}$ on the outer membrane permeabilization and inner membrane integrity of ST.

(A) Time-response curve of the outer membrane permeation of ST cells to NPN. (B) Time-response curve of the inner membrane Integrity of ST cells to DiS- $\mathrm{C}_{3}-(5)$ (C) The $\beta$-galactosidase activity in the culture medium of STpKP302mdtk:lacZ cells treated with BSN-37 and permeabilization mixture. STpKP302mdtk:lacZ cells treated with permeabilization mixture containing Z-buffer, chloroform and sodium dodecyl sulfate and PBS buffer was used as positive and negative control, respectively. 


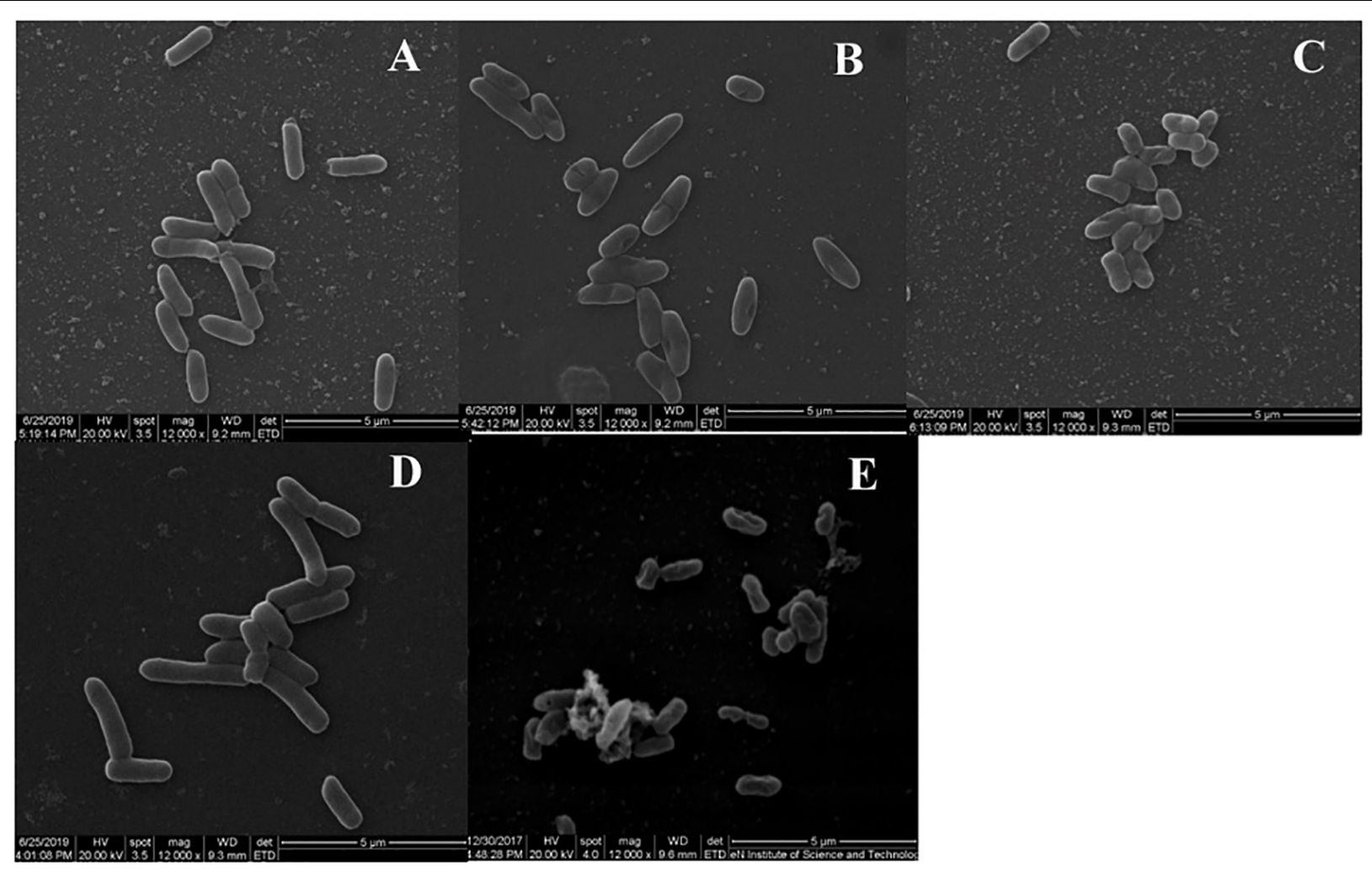

FIGURE 4 | Scanning electron microscropy images of ST treated with BSN-37 and PG for $1 \mathrm{~h}$. (A) ST treated with $50 \mu \mathrm{g} / \mathrm{ml}$ BSN-37; (B) ST treated with $100 \mu \mathrm{g} / \mathrm{ml}$ BSN-37; (C) ST treated with $200 \mu \mathrm{g} / \mathrm{ml} \mathrm{BSN-37;} \mathrm{(D)} \mathrm{ST} \mathrm{treated} \mathrm{with} 10 \mathrm{mM}$ PBS buffer; (E) ST treated with $50 \mu \mathrm{g} / \mathrm{ml}$ pexiganan.

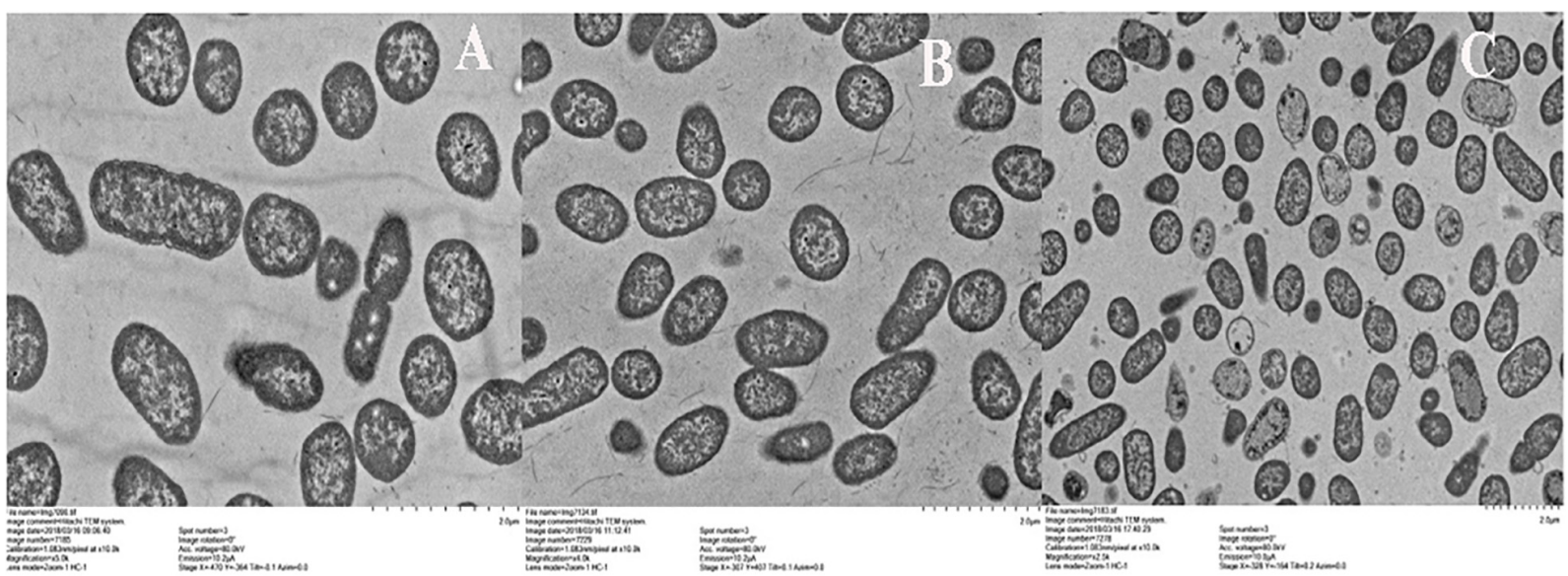

FIGURE 5 | Transmission electron microscropy images of ST treated with BSN-37 and PG for 1 h. (A) ST treated with 10 mM PBS buffer; (B) ST treated with $200 \mu \mathrm{g} / \mathrm{ml} \mathrm{BSN-37;} \mathrm{(C)} \mathrm{ST} \mathrm{treated} \mathrm{with} 50 \mu \mathrm{g} / \mathrm{ml}$ pexiganan.

which demonstrates that BSN-37 does not lyse ST at the tested concentrations.

\section{Cytotoxicity of BSN-37}

The toxicity of BSN-37 to IPEC-J2 cells and Vero cells was investigated using the CCK-8 method and realtime cell analysis via the xCELLigence system. In the
CCK-8 assay, the survival rate of IPEC-J2 cells treated with BSN-37 at the concentration of $50 \mu \mathrm{g} / \mathrm{ml}$ was $82.74 \%$. The survival rates were all greater than $100 \%$ when the concentrations of BSN-37 were 100, 200, and $400 \mu \mathrm{g} / \mathrm{ml}$. As a positive control group, pexiganan showed concentration-dependent cytotoxicity. The survival rate of IPEC-J2 cells was 52.64 and $3.98 \%$ in pexiganan at 


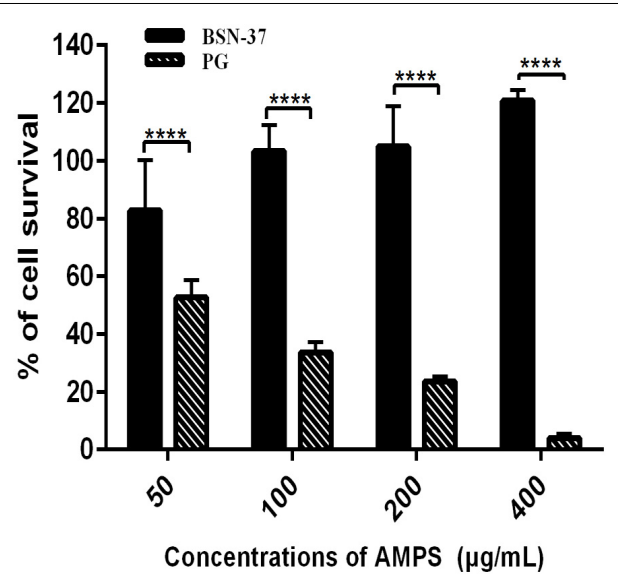

FIGURE 6 | The survival rates of IPEC-J2 cells treated with BSN-37 and PG at a different concentrations by CCK-8 assay. Error bar represents mean \pm SEM, $n=3 .{ }^{* \star * \star}$ represent extremely significance $(P<0.0001$ by two-way ANOVA).

the concentration of 50 and $400 \mu \mathrm{g} / \mathrm{ml}$, respectively, (shown in Figure 6).

In the real-time cell assay, a bidirectional comparison of four groups of two peptides with the same concentration was conducted after the standard cell index (CI) curve was measured. As shown in Figure 7A, all growth curves of IPEC-J2 cells individually treated with five BSN-37 concentrations (50, 100, 200, 400, and $800 \mu \mathrm{g} / \mathrm{ml}$ ) reached the confluence compared to untreated cells, which indicates that BSN-37 did not inhibit the growth of IPEC-J2 cells. In contrast, a significant decrease of CI was immediately observed when IPEC-J2 cells were treated with $100 \mu \mathrm{g} / \mathrm{ml}$ pexiganan, and the growth of IPEC-J2 cells was not recovered during the prolonged incubation of $40 \mathrm{~h}$. Conversely, cell survival rates in the group containing $100 \mu \mathrm{g} / \mathrm{ml} \mathrm{BSN-37}$ and pexiganan were $94.75-99.04 \%$ and $29.92-38.86 \%$, respectively (shown in Figure 7B). The change tendency of growth curves of Vero cells was similar to that of IPEC-J2 cells when treated by different concentrations of BSN-37 (shown in Figure 7C), which implies that BSN-37 also has no toxicity to Vero cells. The survival rates of Vero cells were 101.1-110.46\% in the incubation with $100 \mu \mathrm{g} / \mathrm{ml}$ BSN-37for $40 \mathrm{~h}$ (shown in Figure 7D). Pexiganan led to decreased survival rates of Vero cells in the first incubation for about $6 \mathrm{~h}$ and then cell growth was recovered step by step with the incubation time. The survival rates of Vero cells were $74.17-105.1 \%$ in incubation with pexiganan for $40 \mathrm{~h}$ (shown in Figures 7C,D). Collectively, these results indicated that BSN-37 had no toxicity to the tested cells even when the concentration was $800 \mu \mathrm{g} / \mathrm{ml}$.

\section{Inhibition Activity of BSN-37 Against Intracellular S. Typhimurium}

In the proliferation inhibition assay, the invasion ability of ST and SB217 against MDCK cells was 0.1 and $0.12 \%$, respectively. After the co-culture for $14 \mathrm{~h}$, the increased fold of intracellular replication of ST and SB217 in MDCK cells is $36.23 \pm 5.2$ and $6.08 \pm 0.5$, respectively, (shown in Figure 8). After the MDCK cells harboring ST and SB217 were treated with BSN-37 at the concentration of $400 \mu \mathrm{g} / \mathrm{ml}$ for $14 \mathrm{~h}$, the intracellular replication capacities of these two strains both exhibited significantly decrease compared to that of their corresponding untreated group, which demonstrates that BSN-37 can effectively inhibit the proliferation of intracellular $S$. Typhimurium.

\section{DISCUSSION}

proline-rich peptides contain arginine-rich cationic N-terminal regions followed by more hydrophobic proline-rich repetitions. In aqueous solutions or in lipid vesicles, proline-rich sequences can promote the formation of a left-handed type II polyproline helix that relates to the microbicidal effects of the PRPs (Antonyraj et al., 1998; Otvos, 2002). Alternatively, research has demonstrated that the arginine-rich cationic N-terminal regions also play an important role in the biological activity of PRPs. The structure-activity relationship of Bac5 and Bac7, another PRP from bovine neutrophils, showed that the truncated fragments Bac5(4-23) and Bac7(5-23) lost antibacterial activity when the first three and four amino acid residues were completely removed from their corresponding active fragments, Bac5(1-23) and Bac7(1-23), respectively. The absence of the first arginine residue in the $\mathrm{N}$-terminus of $\mathrm{Bac5}(1-23)$ caused a 2-to 4-fold increase in the MICs of $\mathrm{Bac}(2-23)$ against $S$. aureus IFO 12 732, B. subtilis IFO 3134, and E. coli IFO 12734 (Tokunaga et al., 2001; Benincasa et al., 2004). In addition, the N-terminal variant of PR39(1-15) of PR39, a PRP from the porcine small intestine, did not exhibit biological activity when its first three arginine residues were substituted with asparagine (Chan et al., 2001). Furthermore, research showed that the capacity of the two $\mathrm{N}$-terminal residues forming correct $\mathrm{H}$-bonding had a greater effect on the antibacterial activity of Bac7(1-23) than their steric features and local charges (Guida et al., 2015). In this paper, BSN-37 is a fragment of Bac5 from the 2nd residue to the 38th residue, which showed antibacterial activity against the tested strains except for S. aureus ATCC25923 (Table 1). The MICs of BSN-37 against E. coli ATCC25922 $(33.33 \mu \mathrm{g} / \mathrm{ml})$ exhibited a 2.8fold increase compared to that of Bac5 $(12 \mu \mathrm{g} / \mathrm{ml})$, which may indicate a lack of the first arginine residue in the N-terminal of BSN-37. However, BSN-37 showed strong antibacterial activity against $S$. Typhimurium (MICs, 8.33-16.67 $\mu \mathrm{g} / \mathrm{ml}$ ). This activity is similar to that of Bac5 (MICs, $12-25 \mu \mathrm{g} / \mathrm{ml}$ ) and the truncated fragment Bac5(1-25) [MICs, $8 \mu \mathrm{M}$ (about $25 \mu \mathrm{g} / \mathrm{ml}$ )], which has the best antibiotic potency (Gennaro et al., 1989; Mardirossian et al., 2019). This implies that the first arginine residue in Bac5 has no significant effect on its antibacterial activity against $S$. Typhimurium. The antibacterial activity of Bac5 and its truncated fragments exhibit bacterial-specificity, and $S$. Typhimurium seems to be a good target attacked by these peptides.

The lipopolysaccharide (LPS) monolayer on the outer membrane of Gram-negative bacteria prevents antibacterial agents from entering bacteria. Some ions such as $\mathrm{Ca}^{2+}$ and $\mathrm{Mg}^{2+}$, can stabilize LPS molecules by binding to the negatively charged groups and affecting the antibacterial activity of some drugs (Loh et al., 1984). Most AMPs carry a net positive 


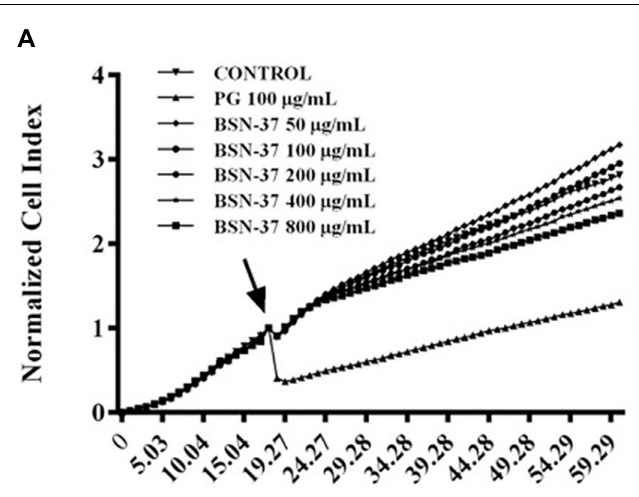

Time(h)

C

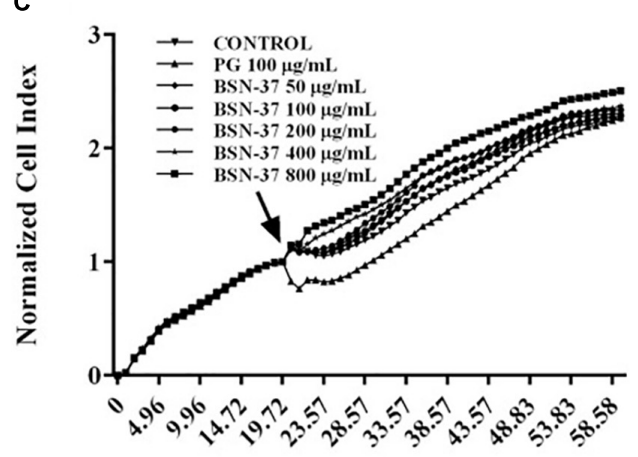

Time(h)

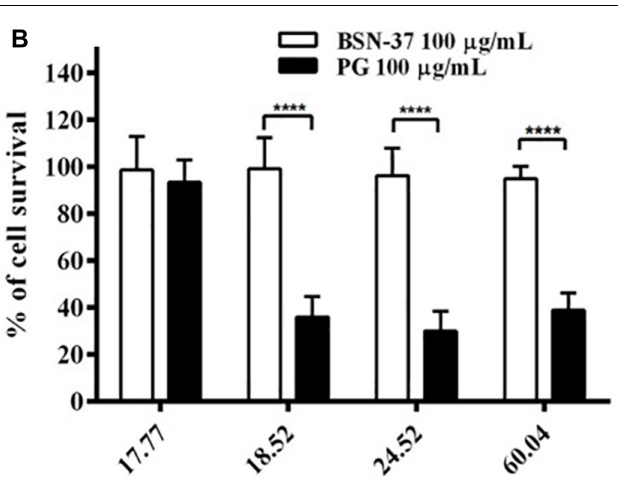

Time(h)

D

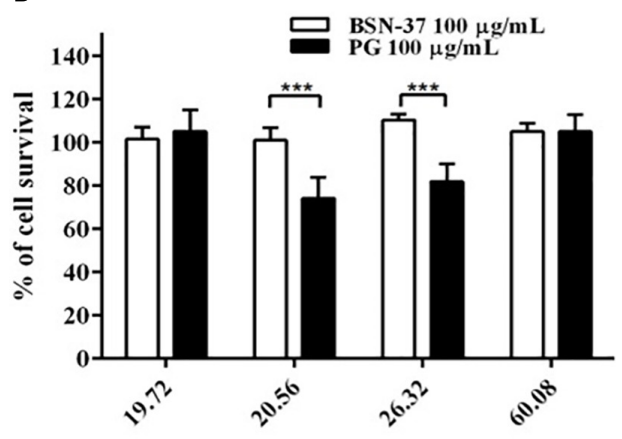

Time(h)

FIGURE 7 | Real-time measurement of the cytotoxicity of BSN-37 and pexiganan against IPEC-J2 cells and Vero cells and the survival rates of IPEC-J2 cells and Vero cells incubated with $100 \mu \mathrm{g} / \mathrm{ml} \mathrm{BSN-37}$ and $100 \mu \mathrm{g} / \mathrm{ml}$ pexiganan for different times. (A,C) Real-time monitoring of the cytotoxicity of IPEC-J2 cells and Vero cells, respectively, treated with BSN-37 at a different concentrations $(50,100,200,400$, and $800 \mu \mathrm{g} / \mathrm{ml})$ and pexiganan at the concentration of $100 \mu \mathrm{g} / \mathrm{ml}$ for $60 \mathrm{~h}$ using the $x$ CELLigence system. The black arrows indicate the time points of adding the peptides. The cells without antimicrobial peptide were used as control. (B,D) parallel comparisons of the survival rates of IPEC-J2 cells and Vero cells, respectively, treated with $100 \mu \mathrm{g} / \mathrm{ml} \mathrm{BSN-37} \mathrm{and} 100 \mu \mathrm{g} / \mathrm{ml}$ pexiganan at specific four time points. Error bars represent means $\pm \mathrm{SEM}, n=3 .{ }^{* * *}$ and ${ }^{* \star *}$ represents very significance and extremely significance, respectively. $(p<0.001$ and $p<0.0001$ by Two-way ANOVA).

charge and can interact with LPS carrying a net negative charge (Ding et al., 2003). Therefore, the ions in serum are important factors affecting the antibacterial activity of AMPs in vivo. The research demonstrated that the presence of $\mathrm{Ca}^{2+}$ or $\mathrm{Mg}^{2+}$ with a concentration of $0.5 \mathrm{mM}$ caused a significant reduction in the bactericidal activity of Bac5 and Bac7 against E. coli ATCC25922 (Gennaro et al., 1989). QaBac5 and ChBac5 had no activity against $C$. albicans 820 with a high concentration of $\mathrm{Na}^{+}$ (100 mM). QaBac5 and CHBac5 also showed similar antibacterial activity against E. coli ML-35p and Listeria monocytogenes EGD at low and high concentrations of $\mathrm{Na}^{+}$. Moreover, ChBac5 showed reduced activity against $S$. Typhimurium14028S at a high concentration of $\mathrm{Na}^{+}$(Shamova et al., 1999). In this study, the physiological concentrations of $\mathrm{NaCl}, \mathrm{MgCl}_{2}$, and $\mathrm{CaCl}_{2}$ significantly decreased the antibacterial activity of BSN37 against E. coli ATCC25922 (increased MICs > 6-fold, Table 2). However, the MICs of BSN-37 against ST did not show remarkable changes in the presence and absence of six salts (increased MICs $<1.5$-fold) except for $\mathrm{CaCl}_{2}$ (increased MICs $\approx 4$-fold). These results demonstrate that the effect of some ions on the antibacterial activity of PRPs is concentration- dependent and bacteria-dependent. BSN-37 may keep relatively stable antibacterial activity against $S$. Typhimurium in vivo.

Most AMPs are cationic and amphipathic molecules that kill bacteria by disrupting the cell membrane through the formation of ion channels or transmembrane pores. PRPs have been shown to kill susceptible organisms by inhibiting the activity of bacterial cytoplasmic targets without causing significant membrane perturbation (Mishra et al., 2018). QaBac5mini, a truncated fragment of QaBac5, and QaBac7.5mini can facilitate the uptake of NPN when interacting with E. coli at the MICs (0.4-0.5 $\mu \mathrm{g} / \mathrm{ml})$. However, QaBac5mini and QaBac7.5mini did not impair the inner membrane integrity above these values (Anderson et al., 2004). Likewise, similar results were observed in the PRPs of ChBac3.4, ChBac5, ChBac7N $\alpha$, and ChBac7N $\beta$ (Shamova et al., 2009; Shamova et al., 2016). These results indicate that the PRPs can reach the bacterial inner membrane by increasing the permeability of the outer membrane in gramnegative bacteria, and PRPs likely enter the cytoplasm with the help of membrane proteins. Research demonstrated that Bac7(135), Bac5(1-25), and Bac5(1-31) entered E. coli by the inner membrane transport proteins, SbmA (Mardirossian et al., 2018; 


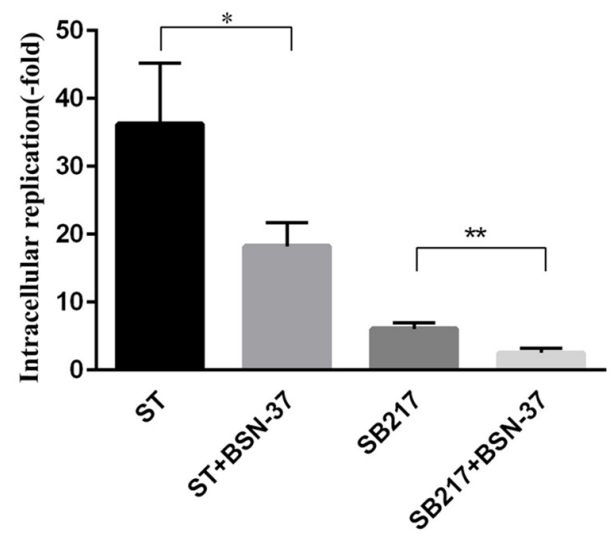

FIGURE 8 | Intracellular replication of ST and SB217 in the presence and absence of BSN-37 in MDCK cells. The concentration of BSN-37 is $400 \mu \mathrm{g} / \mathrm{ml}$. Error bars represent means \pm SEM, $n=3$. Statistical significance was defined as follows: ${ }^{*} P 0.05$ and ${ }^{* *} P<0.01$ (Student's $t$-test).

Mattiuzzo et al., 2007). In this study, $50 \mu \mathrm{g} / \mathrm{ml}$ (8-fold MICs) pexiganan caused significant damage in the outer and inner membrane of ST, which agrees with the action mechanism of forming toroidal pores in the bacterial membrane (Gottler and Ramamoorthy, 2009). In contrast, $200 \mu \mathrm{g} / \mathrm{ml}$ (about 12-fold MICs) BSN-37 increased the outer membrane permeability of ST but did not impair the inner membrane integrity. Simultaneously, no broken or ruptured cells were found in the SEM and TEM figures. This strongly supports that BSN-37 conducts antibacterial activity in the cytoplasm rather than disrupting the bacterial inner membrane. However, during the detection of inner membrane integrity a slight increase (about $50 \mathrm{AU}$ ) of the fluorescence intensity of DiS-C ${ }_{3-}$ (5) was observed after it was incubated with the treated ST for about 2 min, which may be a consequence of an inner membrane disturbance caused by the BSN-37-mediated inhibition of intracellular targets. A similar phenomenon was also reported in E. coli CGSC 4908 treated with an AMP P-Der at $10 \times$ its MIC, which is an amidated hybrid of flounder pleurocidin and frog dermaseptin (Patrzykat et al., 2002). Bac5 can induce respiratory inhibition and drop the ATP content in S. Typhimurium (Skerlavaj et al., 1990). Furthermore, Bac5(1-25), Bac5(1-31), and Bac7(1-35) conducts antibacterial activity by binding to the peptide exit tunnel in the bacterial 70S ribosomes (Mardirossian et al., 2018; Seefeldt et al., 2016). Except for the inhibition of protein synthesis, Bac7 could still prevent chaperon-assisted protein folding by binding to the chaperon protein, DanK, and inhibiting the growth of E. coli in extremely acidic environments by targeting arginine decarboxylase (Ho et al., 2016). In addition, PR-39 can inhibit protein and DNA synthesis. At the same time, PR-39 also participates in a variety of processes, including the promotion of wound repair, induction of angiogenesis, neutrophils, and chemotaxis, and inhibition of phagocyte NADPH oxidase activity by binding to intracellular SH3-containing proteins (Holani et al., 2016). It is with multiple targets in the cytoplasm that bacteria hardly produce resistance to the PRPs.
Some AMPs not only kill the pathogen but also induce cytotoxicity which restricts their future use in clinical practice. In our study, pexiganan exhibited strong antibacterial activity to the tested strains. Additionally, pexiganan produced strong toxicity to IPEC-J2 cells and Vero cells, which align with our previous results (Zhang et al., 2015). However, BSN-37 did not induce toxicity in the tested cells when its concentration was $800 \mu \mathrm{g} / \mathrm{ml}$ (about $178 \mu \mathrm{M}$ ). Interestingly, the survival rate of all IPEC-J2 cells treated with BSN-37 at the concentration $\geq 100 \mu \mathrm{g} / \mathrm{ml}$ were over $100 \%$. Research demonstrated that Bac5(1-31) displayed concentration-dependent toxicity against NIH 3T3 cells, which was significant at $32 \mu \mathrm{M}$ (Mardirossian et al., 2018). Bac5(125 ) caused a $30 \%$ decrease of the viability of MEC-1 cells when its concentration was $64 \mu \mathrm{M}$ (Mardirossian et al., 2019). Moreover, ChBac3.4 at its $\mathrm{IC}_{50}$ exhibited toxicity to K-562 cells and U-937 cells but no toxicity to A-549 cells, MRC-5cells, and normal human skin fibroblasts (Shamova et al., 2009). Therefore, the effect of BSN-37 on other eukaryotic cells still need further studied.

BSN-37 exhibits strong activity against $S$. Typhimurium in vitro and were non-toxic to the tested eukaryotic cells; therefore, this study investigated the effect of BSN-37 on the inhibition of the proliferation of intracellular $S$. Typhimurium. The results showed that BSN-37 significantly reduced the amount of intracellular S. Typhimurium, which suggests that BSN-37 can enter MDCK cells and kill intracellular S. Typhimurium. It has been reported that $\mathrm{Bac} 7(1-35)$ could be rapidly taken into $3 \mathrm{~T} 3$ and U937 cells through a non-toxic energy- and temperaturedependent process (Tomasinsig et al., 2006). Furthermore, Ba7(135) was used to treat the mice infected by $S$. Typhimurium. The peptide significantly increased the number of survivors and the mean survival times of treated mice. Likewise, Ba7(135) also remarkably reduced the bacterial load in the organs of treated mice (Benincasa et al., 2010). Unfortunately, no member of Bac5 and its truncated fragments were used to perform animal experiments until now. Although BSN-37 exhibits good characteristics in vitro against $S$. Typhimurium, many experiments need to be performed in the future to select a potential candidate for the development of antiSalmonella agents.

\section{CONCLUSION}

We investigated the characteristics of a novel AMP BSN-37, which showed good antibacterial activity and relative ionic stability against $S$. Typhimurium. BSN-37 at the concentration of $100 \mu \mathrm{g} / \mathrm{ml}$ could kill $S$. Typhimurium after co-incubation for $6 \mathrm{~h}$. The bactericidal mechanism of BSN-37 is a non-lysis action model. Likewise, BSN-37 did not exhibit cell toxicology even at $800 \mu \mathrm{g} / \mathrm{ml}$ and significantly inhibited the proliferation of intracellular S. Typhimurium.

\section{DATA AVAILABILITY STATEMENT}

The datasets generated for this study are available on request to the corresponding author. 


\section{AUTHOR CONTRIBUTIONS}

YS and JH conceived and designed the experiments. LY, KZ, $\mathrm{BHu}$, and YC performed the experiments. YX, BHa, and LW contributed reagents, materials, and analysis tools. YS and XX wrote the manuscript.

\section{REFERENCES}

Anderson, R. C., Hancock, R. E. W., and Yu, P. L. (2004). Antimicrobial activity and bacterial-membrane interaction of ovine-derived cathelicidins. Antimicrob. Agents Chemother. 48, 673-676. doi: 10.1128/aac.48.2.673-676.2004

Anderson, R. C., and Yu, P. L. (2003). Isolation and characterisation of proline/arginine-rich cathelicidin peptides from ovine neutrophils. Biochem. Biophy.s Res. Commun. 312, 1139-1146. doi: 10.1016/j.bbrc.2003.11.045

Antonyraj, K. J., Karunakaran, T., and Antony, R. P. (1998). Bactericidal Activity and Poly-L-proline II conformation of the tandem repeat sequence of human salivary mucin glycoprotein (MG2). Arch. Biochem. Biophys. 356, 197-206. doi: 10.1006/abbi.1998.0779

Balasubramanian, R., Im, J., Lee, J. S., Jin, J. H., Mogeni, O. D., Kim, J. H., et al. (2019). The global burden and epidemiology of invasive non-typhoidal Salmonella infections. Hum. Vaccin. Immun. Ther. 15, 1421-1426. doi: 10.1080/ 21645515.2018.1504717

Benincasa, M., Pelillo, C., Zorzet, S., Garrovo, C., Biffi, S., Gennaro, R., et al. (2010). The proline-rich peptide Bac7(1-35) reduces mortality from Salmonella typhimurium in a mouse model of infection. BMC Microbiol. 10:178. doi: 10. 1186/1471-2180-10-178

Benincasa, M., Scocchi, M., Podda, E., Skerlavaj, B., Dolzani, L., and Gennaro, R. (2004). Antimicrobial activity of Bac7 fragments against drug-resistant clinical isolates. Peptides 25, 2055-2061. doi: 10.1016/j.peptides.2004.08.004

Chan, Y. R., Zanetti, M., Gennaro, R., and Gallo, R. L. (2001). Anti-microbial activity and cell binding are controlled by sequence determinants in the antimicrobial Peptide PR-39. J Invest Dermatol 116, 230-235. doi: 10.1046/j.15231747.2001.01231.x

Clinical and Laboratory Standards Institute [CLSI] (2017). Performance Standards for Antimicrobial Susceptibility Testing; Supplement M100, 27th Edn. Wayne, PA: Clinical and Laboratory Standards Institute.

Crump, J. A., Sjölund-Karlsson, M., Gordon, M. A., and Parry, C. M. (2015). Epidemiology, clinical presentation, laboratory diagnosis, antimicrobial resistance, and antimicrobial management of invasive Salmonella infections. Clin. Microbiol. Rev. 28, 901-937. doi: 10.1128/CMR.00002-15

Ding, L., Yang, L., Weiss, T. M., Waring, A. J., Lehrer, R. I., and Huang, H. W. (2003). Interaction of antimicrobial peptides with lipopolysaccharides. Biochemistry 42, 12251-12259. doi: 10.1021/bi035130\%2B

Gennaro, R., Skerlavaj, B., and Romeo, D. (1989). Purification, composition, and activity of two bactenecins, antibacterial peptides of bovine neutrophils. Infect. Immun. 57, 3142-3146. doi: 10.1128/iai.57.10.3142-3146. 1989

Gerlach, R. G., Cláudio, N., Rohde, M., Jäckel, D., Wagner, C., and Hensel, M. (2008). Cooperation of Salmonella pathogenicity islands 1 and 4 is required to breach epithelial barriers. Cell Microbiol. 10, 2364-2376. doi: 10.1111/j.14625822.2008.01218.x

Gottler, L. M., and Ramamoorthy, A. (2009). Structure, membrane orientation, mechanism, and function of pexiganan - a highly potent antimicrobial peptide designed from magainin. Biochim. Biophys. Acta 1788, 1680-1686. doi: 10.1016/j.bbamem.2008.10.009

Guida, F., Benincasa, M., Zahariev, S., Scocchi, M., Berti, F., Gennaro, R., et al. (2015). Effect of size and N-terminal residue characteristics on bacterial cell penetration and antibacterial activity of the Proline-rich Peptide Bac7. J. Med. Chem. 58, 1195-1204. doi: 10.1021/jm501367p

Helander, I. M., and Mattila-Sandholm, T. (2000). Fluorometric assessment of gram-negative bacterialpermeabilization. J. Appl. Microbiol. 88, 213-219. doi: 10.1046/j.1365-2672.2000.00971.x

Ho, Y. H., Shah, P., Chen, Y. W., and Chen, C. S. (2016). Systematic analysis of intracellular-targeting antimicrobial peptides, Bactenecin 7 , hybrid of pleurocidin and dermaseptin, proline-Arginine rich peptide, and Lactoferricin

\section{FUNDING}

This work was supported by the National Natural Science Foundation of China (No. 31972715) and National Natural Science Foundation of China-Henan Talent Training Joint fund (U1504327).

B, by using Escherichia coli proteome microarrays. Mol. Cell Proteomics 15, 1837-1847. doi: 10.1074/mcp.M115.054999

Holani, R., Shah, C., Haji, Q., Inglis, G. D., Uwiera, R. R. E., and Cobo, E. R. (2016). Proline-arginine Rich (PR-39) cathelicidin: structure, expression and functional implication in intestinal health. Comp. Immunol. Microbiol. Infect. Dis. 49, 95-101. doi: 10.1016/j.cimid.2016.10.004

Loh, B., Grant, C., and Hancock, R. E. W. (1984). Use of the fluorescent probe 1-Nphenylnaphthylamine to study the interactions of aminoglycoside antibiotics with the outer membrane of Pseudomonas aeruginosa. Antimicrob. Agents Chemother. 26, 546-551. doi: 10.1128/aac.26.4.546

Maisetta, G., Luca, M. D., Esin, S., Florio, W., Brancatisano, F. L., Bottai, D., et al. (2018). Evaluation of the inhibitory effects of human serum components on bactericidal activity of human Beta defensin 3. Peptides 2, 1-6. doi: 10.1016/j. peptides.2007.10.013

Mardirossian, M., Barrière, Q., Timchenko, T., Müller, C., Pacor, S., Mergaert, P., et al. (2018). Fragments of the nonlytic proline-Rich antimicrobial peptide Bac5 Kill Escherichia coli Cells by inhibiting protein synthesis. Antimicrob. Agents Chemothe.r 62:AAC.00534-18. doi: 10.1128/AAC.00534-18

Mardirossian, M., Sola, R., Degasperi, M., and Scocchi, M. (2019). Search for shorter portions of the proline-rich antimicrobial peptide fragment Bac5(1-25) that retain antimicrobial activity by blocking protein synthesis. Chem. Med. Chem. 14, 343-348. doi: 10.1002/cmdc.201800734

Mattiuzzo, M., Bandiera, A., Gennaro, R., Benincasa, M., Pacor, S., Antcheva, N., et al. (2007). Role of the Escherichia coli SbmA in the antimicrobial activity of Proline-rich peptides. Mol. Microbiol. 66, 151-163. doi: 10.1111/j.1365-2958. 2007.05903.x

Mishra, A., Choi, J., Moon, E., and Baek, K. H. (2018). Tryptophan-rich and proline-rich antimicrobial peptides. Molecules 23, 1-23. doi: 10.3390/ molecules 23040815

Otvos, L. (2002). The short proline-rich antibacterial peptide family. CMLS Cell Mol. Life Sci. 59, 1138-1150. doi: 10.1007/s00018-002-8493-8

Patrzykat, A., Friedrich, C. L., Zhang, L. J., Mendoza, V., and Hancock, R. E. W. (2002). Sublethal concentrations of pleurocidin-derived antimicrobial peptides inhibit macromolecular synthesis in Escherichia coli. Antimicrob. Agents Chemother. 46, 605-614. doi: 10.1128/aac.46.3.605-614.2002

Pauly, D., Worbs, S., Kirchner, S., Shatohina, O., Dorner, M. B., and Dorner, B. G. (2012). Real-Time cytotoxicity assay for rapid and sensitive detection of ricin from complex matrices. PLoS One 7:e35360. doi: 10.1371/journal.pone.0035360

Paytubi, S., Cansado, C., Madrid, C., and Balsalobre, C. (2017). Nutrient composition promotes switching between pellicle and bottom biofilm in Salmonella. Front. Microbiol. 8:2160. doi: 10.3389/fmicb.2017.02160

Price, R. L., Bugeon, L., Mostowy, S., Makendi, C., Wren, B. W., Williams, H. D., et al. (2019). In vitro and in vivo properties of the bovine antimicrobial peptide, bactenecin 5. PLoS One 14:e0210508. doi: 10.1371/journal.pone.0210508

Ramanathan, B., Davis, E. G., Ross, C. R., and Blecha, F. (2002). Cathelicidins: microbicidal activity, mechanisms of action, and roles in innate immunity. Microbes Infect. 4, 361-372. doi: 10.1016/s1286-4579(02)01549-6

Sautrey, G., Khoury, M. E. I, Santos, A. G., Zimmermann, L., Deleu, M., Lins, L., et al. (2016). Negatively charged lipids as a potential target for new amphiphilic aminoglycoside antibiotics. J. Biol. Chem. 291, 13864-13874. doi: 10.1074/jbc. M115.665364

Scocchl, M., Skeplavaj, B., Romeo, D., and Gennaro, R. (1992). proteolytic cleavage by neutrophil elastase converts inactive storage proforms to antibacterial bactenecins. Eur. J. Biochem. 209, 589-595. doi: 10.1111/j.1432-1033.1992. tb17324.x

Seefeldt, A. C., Graf, M., Pérébaskine, N., Nguyen, F., Arenz, S., Mardirossian, M., et al. (2016). Structure of the mammalian antimicrobial peptide Bac7(116) bound within the exit tunnel of a bacterial ribosome. Nucleic Acids Res. 44, 2429-2438. doi: 10.1093/nar/gkv1545 
Shamova, O., Brogden, K. A., Zhao, C. Q., Nguyen, T., Kokryakov, V. N., and Lehrer, R. I. (1999). Purification and properties of proline-rich antimicrobial peptides from sheep and goat leukocytes. Infect. Immun. 67, 4106-4111. doi: 10.1128/iai.67.8.4106-4111.1999

Shamova, O., Orlov, D., Stegemann, C., Czihal, P., Hoffmann, R., Brogden, K., et al. (2009). ChBac3.4: a novel proline-rich antimicrobial peptide from Goat leukocytes. Int. J. Pept. Res. Ther. 15, 107-119. doi: 10.1007/s10989-009-9170-7

Shamova, O. V., Orlov, D. S., Zharkova, M. S., Balandin, S. V., Yamschikova, E. V., Knappe, D., et al. (2016). Minibactenecins ChBac7.N $\alpha$ and ChBac7.N $\beta$ - Antimicrobial Peptides from Leukocytes of the Goat Capra hircus. Acta Nat. 8, 136-146. doi: 10.32607/20758251-2016-8-3-136-146

Shao, C. X., Tian, H. T., Wang, T. Y., Wang, Z. H., Chou, S. L., Shan, A. S., et al. (2018). Central $\beta$-turn increases the cell selectivity of imperfectly amphipathic $\alpha$-helical peptides. Acta Biomater. 69, 243-255. doi: 10.1016/j.actbio.2018. 01.009

Skerlavaj, B., Romeo, D., and Gennaro, R. (1990). Rapid membrane permeabilization and inhibition of vital functions of gram-negative bacteria by bactenecins. Infect. Immun. 58, 3724-3730. doi: 10.1128/iai.58.11.3724-3730. 1990

Spänig, S., and Heider, D. (2019). Encodings and models for antimicrobial peptide classification for multi-resistant pathogens. Biodata Mining 12, 1-29. doi: 10. 1186/s13040-019-0196-X

Tokunaga, Y., Niidome, T., Hatakeyama, T., and Aoyagi, H. (2001). Antibacterial activity of bactenecin 5 fragments and their interaction with phospholipid membranes. J Pept. Sci. 7, 297-304. doi: 10.1002/psc.317

Tomasinsig, L., Skerlava, B., Papo, N., Giabbai, B., Shai, Y., and Zanetti, M. (2006). Mechanistic and functional studies of the interaction of a prolinerich antimicrobial peptide with mammalian cells. J. Biol. Chem. 281, 383-391. doi: 10.1074/jbc.m510354200
Treffers, C., Chen, L. Y., Anderson, R. C., and Yu, P. L. (2005). Isolation and characterisation of antimicrobial peptides from deer neutrophils. Int. J. Antimicrob. Agents 26, 165-169. doi: 10.1016/j.ijantimicag.2005. 05.001

Yang, L., Hang, B. L., Xu, Y. Z., Wang, L., Xia, X. J., Dong, M. M., et al. (2018). Biological activity of a novel bovine-borne antimicrobial peptide BSN-37. Chin. J. Vet. Sci. 38, 2088-2093.

Zanetti, M., Litteri, L., Gennaro, R., Horstmann, H., and Romeo, D. (1990). Bactenecins, defense polypeptides of bovine neutrophils, are generated from precursor molecules stored in the large granules. J. Cell Biol. 11, 1363-1371. doi: $10.1083 /$ jcb.111.4.1363

Zhang, Q. H., Xu, Y. Z., Wang, Q., Hang, B. L., Sun, Y. W., Wei, X. X., et al. (2015). Potential of novel antimicrobial peptide P3 from bovine erythrocytes and its analogs to disrupt bacterial membranes in vitro and display activity against drug-resistant bacteria in a mouse model. Antimicrob. Agents Chemother. 59, 2835-2841. doi: 10.1128/AAC.04 932-14

Conflict of Interest: The authors declare that the research was conducted in the absence of any commercial or financial relationships that could be construed as a potential conflict of interest.

Copyright (c) 2020 Yang, Sun, Xu, Hang, Wang, Zhen, Hu, Chen, Xia and Hu. This is an open-access article distributed under the terms of the Creative Commons Attribution License (CC BY). The use, distribution or reproduction in other forums is permitted, provided the original author(s) and the copyright owner(s) are credited and that the original publication in this journal is cited, in accordance with accepted academic practice. No use, distribution or reproduction is permitted which does not comply with these terms. 